\title{
THE EVOLUTION OF THE AGRICULTURAL SECTOR IN CENTRAL AND EAST EUROPEAN COUNTRIES AFTER 12 YEARS OF MEMBERSHIP IN THE EU ON THE EXAMPLE OF POLAND
}

Jakub Piecuch ${ }^{1}, \mathrm{PhD}$ with habilitation, associate professor; Lukasz Paluch ${ }^{2}, \mathrm{PhD}$

1,2 University of Agriculture in Krakow, Institute of Economics and Social Sciences, Department of Economics and Economic Policy, Poland

\begin{abstract}
Accession to the European Union was one of more important factors determining the scale and rate of changes in the agricultural sector in Central and East European countries in the years 2004-2016. Actions of the European Union arising from the functioning of the Common Agricultural Policy and instruments associated therewith (mainly in the form of structural funds) provided the countries entering the Community after 2004 with a wide range of benefits. Those benefits included a reduction in the number of farms, an increase in the average size of farm, improvement of farm technical equipment, an increase in the exports of agricultural commodities, intensification of organic production, restructuring the markets for agricultural products and services, improvement of living conditions of rural population. The changes observed in the last 12 years did not have a uniform character or rate, which is associated with a distinct variety in level of social and economic development and in environmental conditions of the so-called eastern countries of the Old Continent, that is the Czech Republic, Estonia, Lithuania, Latvia, Hungary, Slovakia, Poland and their regions. Therefore, the aim of this research is to attempt to show selected developmental changes in the agricultural sector in Central and East European countries after 12 years of membership in the European Union as well as to identify and assess the level of agricultural development in the regional arrangement on the example of Poland. The level of development of Polish agriculture in the regional arrangement was assessed using PERKAL's method of standardized sums (which belongs to the group of taxonomic methods), where the starting point was to propose a set of diagnostic features which in a possibly complete manner would allow to assess the level of agricultural development in 16 regions of Poland in the years 2015-2016.
\end{abstract}

Keywords: European Union, agriculture, Polish regions, taxonomic methods, PERKAL index. JEL code: C43, Q51, Q56, R11, R58

\section{Introduction}

The first 21st century enlargement of the EU to the East included in its scope countries of Central and Eastern Europe and led to a situation similar to the full accession of Greece, Spain and Portugal to the European Union in the mid-1980s, known as the Southern Enlargement. In both cases, the enlargements opened up unlimited opportunities for new countries but also created a dilemma for current Member States. These problems were connected with a great potential of agricultural production in new Member States, especially Poland (being the biggest economy among them), and their competitiveness in an area of low cost production. After years of development in the framework of the EU common market, man can say it was not justified. Both previous and new Member States have experienced benefits from common cooperation but adjustments which took place in Mediterranean countries also show that the necessity of structural changes still lies ahead of Polish agriculture.

Last enlargements of the European Union to the East have created more development opportunities for Polish economy and its primary sector, especially now during the greatest economic recession in decades. But last enlargements have also led to a situation where approximately $90 \%$ of the European Union territory is covered by rural areas and over half of the EU population lives there. It means that even today, in the second decade of the 21st century, agriculture is still an important sector of economy, and rural development enhanced by the Common Agriculture Policy still plays an important role in Poland. Agriculture not only plays a significant role in Polish GDP but is very often crucial for improving the standard of living of rural 
communities. Majority of countries located in the Central and Eastern part of Europe, like the Czech Republic, Estonia, Latvia, Lithuania, Hungary, Poland and Slovakia, can be described as less developed economies with strong dependence on agricultural production. The position of those countries is somehow underprivileged due to the distance to major European markets. Possibilities of agricultural development in these countries are also limited by scattered agrarian structure, small average area of farms and high variability of environmental factors (i.e. high variability of relief, soil quality classes and water resources) (Mountain areas..., 2004).

Therefore, the aim of this research is to attempt to show selected developmental changes in the agricultural sector in Central and East European countries after 12 years of membership in the European Union as well as to identify and assess the level of agricultural development in the regions of Poland.

\section{Data and methods}

Identification of selected changes in the agricultural sector in Central and East European countries (Czech Republic, Estonia, Latvia, Lithuania, Hungary, Slovakia and Poland) was conducted basing on publications and data of the European Statistical Office (EUROSTAT) and of the Central Statistical Office of Poland (CSOP). The carried out analysis of the above-mentioned EU countries from the macroeconomic perspective focused on the years 2004, 2010 and 2016. The level of development of Polish agriculture in the regional arrangement was assessed using PERKAL's method of standardized sums (which belongs to the group of taxonomic methods), where the starting point was to propose a set of diagnostic features which in a possibly complete manner would allow to assess the level of agricultural development in 16 regions of Poland in the years 2015-2016 (Table 1).

The condition for selecting the diagnostic variables was the assumption that they would be reliable, accurate, comparable, adequate and complete with regard to time and space (Grabinski T., 1984). The final list was selected based on a substantive criterion (taking into account the goal, subject and timeframe of the research) as well as a formal criterion (assuming that they should be weakly intercorrlated so as not to copy information, and that they should show a relatively high level of variability, that is higher than $10 \%$ ) (Parris T. M. and Kates R. W., 2003). 
Final set of diagnostic variables

\begin{tabular}{|c|c|}
\hline \multicolumn{2}{|r|}{ Environmental characteristics } \\
\hline $\mathbf{X}_{1}(\mathbf{s})$ & share of agricultural land in total area ( \%) \\
\hline $\mathbf{X}_{2}(\mathrm{D})$ & share of fallow land in total agricultural land area ( \%) \\
\hline $\mathbf{X}_{3} \mathbf{( s )}$ & valorization index of agricultural production area \\
\hline $\mathbf{X} 4 \mathbf{( s )}$ & share of the area of organic farms in total agricultural land area ( \%) \\
\hline $\mathbf{X}_{5}$ (D) & consumption of mineral fertilizers NPK ( $k g$ per ha $A L$ ) \\
\hline $\mathbf{X}_{6}(\mathbf{s})$ & consumption of lime fertilizers ( $k g$ per ha $A L$ ) \\
\hline $\mathbf{X}_{7}$ (s) & share of protected areas in total area ( \%) \\
\hline \multicolumn{2}{|r|}{ Economic characteristics } \\
\hline $\mathbf{X}_{8}(\mathbf{s})$ & average area of a farm (ha $A L$ ) \\
\hline $\mathbf{X 9}(\mathbf{s})$ & share of large-area farms in total number of farms ( \%) \\
\hline $\mathbf{X}_{10}(\mathbf{s})$ & share of crops in total area of crops in Poland ( \%) \\
\hline $\mathbf{X}_{11}(\mathbf{s})$ & share of farm animals in total number of farm animals in Poland ( $\%)$ \\
\hline $\mathbf{X}_{12}(\mathbf{s})$ & share of commercial agricultural production in the final agricultural production \\
\hline $\mathbf{X}_{13}(\mathbf{s})$ & capital expenditures in agriculture and hunting [PLN per ha AL] \\
\hline $\mathbf{X}_{14}(\mathbf{s})$ & gross value of fixed assets in agriculture and hunting (million PLN) \\
\hline $\mathbf{X}_{15}(\mathbf{s})$ & share of agriculture in the generated gross value added $(\%)$ \\
\hline \multicolumn{2}{|r|}{ Social characteristics } \\
\hline $\mathbf{X}_{16}(\mathbf{s})$ & population density in rural areas (people per $\mathrm{km}^{2}$ ) \\
\hline $\mathbf{X}_{17}$ (D) & non-working age population per 100 persons of working age \\
\hline $\mathbf{X}_{18}(\mathbf{s})$ & migration balance in rural areas \\
\hline $\mathbf{X}_{19}(\mathbf{s})$ & number of people employed in agriculture (per 100 ha AL) \\
\hline $\mathbf{X}_{20}(\mathrm{D})$ & share of unemployed persons in rural areas in the total number of the unemployed $(\%)$ \\
\hline $\mathbf{X}_{21}(\mathbf{s})$ & share of households where income from agriculture constituted $>50 \%$ of total income $(\%)$ \\
\hline $\mathbf{X}_{22}(\mathbf{s})$ & share of farms where person in charge has higher education in the total number of farms $(\%)$ \\
\hline
\end{tabular}

Identification of the character of diagnostic features assumed for assessment of the investigated phenomenon was carried out by determining whether they represent a positive or negative effect on its course. Investigating their identity led to classifying them into one of two subsets, i.e. the stimulants (S), whose higher values indicate a high level of development of the analysed phenomenon, or the destimulants (D), where high values indicate a distant position in the ranking under construction (Kukula K., 2000). In the case of diagnostic variables assumed for assessment of the level of agricultural development in Polish regions, the set of stimulants was constituted of: $x_{1}, x_{3}, x_{4}, x_{6}, x_{7}, x_{8}, x_{9}, x_{10}, x_{11}, x_{12}, x_{13}, x_{14}, x_{15}, x_{16}, x_{18}, x_{19}, x_{21}, x_{22}$, while $x_{2}, x_{5}, x_{17}, x_{20}$ gained the status of destimulants. Identification of the character of the proposed features formed the basis for the process of their transformation in order to lead to comparability. This is because these features are expressed through different measurement units, with varied accuracy, and their values are characterized by a different range of variability. That is why it was necessary to standardize and set the range of assumed values. The standardization method was the tool which was used to standardize the selected diagnostic features. This method is a form of ratio transformation, where values of a diagnostic feature diminished by its arithmetic mean are compared to the standard deviation (Perkal J., 1954). 


$$
\mathrm{zij}=\left(x \mathrm{ij}-\bar{x}_{j}\right) / \mathrm{S}(\mathrm{xj}) \quad \mathrm{xj} \in \mathrm{S}, \quad \mathrm{zij}=\left(\bar{x}_{j}-\mathrm{xij}\right) / \mathrm{S}(\mathrm{xj}) \quad \mathrm{xj} \in \mathrm{D},
$$

where:

$z_{i j}$ - value of a diagnostic variable after standardization, $x_{i j}$ - value of a diagnostic variable, $\bar{x}_{j}-$ arithmetic mean, $S\left(X_{j}\right)$ - standard deviation, $S$ - set of stimulants, $D$ - set of destimulants.

The standardized features were then used for constructing PERKAL index (PI) which allows to sort out a complex phenomenon with a single numerical measure, in this case the arithmetic mean (Mlodak A., 2006).

$$
\mathrm{PI}=\sum_{i=0}^{n} z_{i j} / \mathrm{n} \quad(\mathrm{i}=1,2, \ldots, \mathrm{r})
$$

where:

$P I$ - value of PERKAL index, $z_{i j}$ - value of a diagnostic variable after standardization, $n$ - number of investigated objects.

The values of determined PERKAL index (PI) allowed to create a ranking of Polish regions according to their level of agricultural development. This index also made it possible to classify the studied objects into three typological groups with a diverse level of agricultural development (Table 2).

Table 2

\section{Criteria of the division of Polish regions into groups with diverse levels of agricultural development}

\begin{tabular}{|l|l|}
\hline \multicolumn{1}{|c|}{ Group } & \multicolumn{1}{c|}{ Criteria of division } \\
\hline A & $\max (\mathrm{PI})-1 / 3[\max -\min (\mathrm{PI})] \leq \mathrm{PI} \leq \max (\mathrm{PI})$ \\
\hline B & $\max (\mathrm{PI})-2 / 3[\max -\min (\mathrm{PI})] \leq \mathrm{PI} \leq \max (\mathrm{PI})-1 / 3[\max -\min (\mathrm{PI})]$ \\
\hline C & $\min (\mathrm{PI}) \leq \mathrm{PI} \leq \max (\mathrm{PI})-1 / 3[\max -\min (\mathrm{PI})]$ \\
\hline
\end{tabular}

Source: authors' elaboration based on Kukula, 2000; Paluch, 2015

When creating the groups, the minimum and maximum values of PERKAL index (PI) were used. The presented division criteria indicate that the higher the value assumed by the synthetic measure (PI), the higher the level of the phenomenon which characterizes a given object, which caused its classification into a particular group in an ascending order, i.e. group $A$ is composed of objects with the highest level, objects with medium levels were classified into group $B$, whereas group $C$ comprises objects with the lowest development of the studied phenomenon (Paluch L., 2015).

\section{Research results and discussion}

Despite all the efforts which have been undertaken in recent years - contrary to the tendencies of developed economies - employment in agriculture is very high, with small farms still dominating, and suffers from a lack of many natural resources, capital and knowledge (Potori $\mathrm{N}$. et al., 2014). As a result, the dominant traditional agriculture is still not adapted to market conditions imposed by common market and is still heavily dependent on agricultural production. This factor, as well as the distance of the mentioned regions from major economic markets, creates a significant barrier to their economic development. It is therefore necessary to change the profile of business activity, by limiting the role of agriculture (which is currently dominant) and shifting the emphasis toward other sectors. Over the past years, a significant structural change has taken place in this area throughout the ongoing outflow of agricultural workers to other sectors of economy, mainly manufacturing or construction (Pogorzelski K., 2014).

Improving the quality of life for local communities will also help to stop negative demographic trends, including migration to more developed regions. In this context many positive changes can 
be noticed in Poland's agriculture. During the last years, we have witnessed, among other things, a spectacular decrease in the contribution of the agricultural sector to the total employment. Along with the decrease in employment, the contribution of the primary sector to the total value added has changed significantly over the last decade. Both changes have led to a major improvement in agriculture production in terms of efficiency. Agriculture in Poland has definitely improved its competitiveness in global food markets, but this is more a result of low cost production than of the effectiveness of the production process.

In 2004, there was more than $6 \%$ of labour force working in the agricultural sector in the EU28 (Table 3). With successive enlargements of the European Union, the number of workers employed in agriculture rose to over 12 million in 2010 (5.4\% of labour force in EU28) and evolved to the level of 10 million in 2016 (4.5\% of labour force in EU28). Those changes in figures for 2010 and 2016 were due to the accession of Czech Republic, Estonia, Latvia, Lithuania, Hungary, Poland and Slovakia. But if we take into account only the changes in situation in New Member States, the number of jobs in the agricultural sector is declining rapidly. In those years, employment in Poland decreased from almost $18 \%$ in 2004 to less than $11 \%$ of labour force in 2016.

Table 3

Employment by sectors in selected countries of Central and Eastern Europe ( \%)

\begin{tabular}{|c|c|c|c|c|c|c|c|c|c|c|c|c|}
\hline \multirow[b]{2}{*}{$\begin{array}{l}\text { Member } \\
\text { State }\end{array}$} & \multicolumn{3}{|c|}{ Agriculture } & \multicolumn{3}{|c|}{ Industry } & \multicolumn{3}{|c|}{ Construction } & \multicolumn{3}{|c|}{ Services } \\
\hline & $\begin{array}{l}\text { षे } \\
\text { 유 }\end{array}$ & 우 & 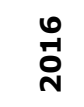 & $\begin{array}{l}\text { ষ } \\
\text { ㅇ }\end{array}$ & $\begin{array}{l}0 \\
\text { O } \\
\text { O }\end{array}$ & $\begin{array}{l}0 \\
\stackrel{0}{0} \\
\text { N }\end{array}$ & $\begin{array}{l}\text { ঠ } \\
\text { ㅇ }\end{array}$ & $\begin{array}{l}\text { 우 } \\
\text { 유 }\end{array}$ & $\begin{array}{l}0 \\
\stackrel{1}{1} \\
\stackrel{+}{N}\end{array}$ & $\begin{array}{l}\text { ঠ } \\
\text { ㅇ }\end{array}$ & $\begin{array}{l}\text { 우 } \\
\text { 유 }\end{array}$ & $\begin{array}{l}0 \\
\stackrel{1}{1} \\
\stackrel{+}{N}\end{array}$ \\
\hline EU 28 & 6.2 & 5.4 & 4.5 & 17.9 & 15.8 & 15.3 & 7.2 & 7.1 & 6.3 & 68.7 & 71.8 & 73.9 \\
\hline Czech Rep. & 3.9 & 3.1 & 3.1 & 29.9 & 27.3 & 29.0 & 8.8 & 9.3 & 7.8 & 57.4 & 60.3 & 60.1 \\
\hline Estonia & 5.8 & 4.2 & 3.9 & 26.2 & 22.2 & 21.0 & 7.6 & 6.7 & 7.3 & 60.4 & 66.9 & 67.8 \\
\hline Latvia & 10.8 & 7.8 & 7.6 & 19.3 & 16.4 & 15.9 & 7.0 & 6.9 & 6.8 & 62.9 & 68.8 & 69.7 \\
\hline Lithuania & 15.6 & 8.8 & 8.0 & 20.0 & 17.6 & 17.5 & 8.0 & 7.0 & 7.6 & 56.4 & 66.6 & 66.9 \\
\hline Hungary & 8.8 & 7.2 & 5.9 & 24.4 & 22.5 & 19.7 & 7.1 & 6.7 & 6.3 & 59.7 & 63.6 & 68.1 \\
\hline Poland & 17.9 & 13.0 & 10.6 & 23.3 & 22.1 & 23.7 & 5.8 & 7.9 & 7.2 & 53.0 & 56.9 & 58.5 \\
\hline Slovakia & 4.7 & 3.4 & 3.1 & 27.0 & 23.6 & 23.9 & 6.8 & 8.5 & 7.2 & 61.5 & 64.6 & 65.8 \\
\hline
\end{tabular}

Source: authors' calculation based on data from the European Statistical Office, 2017

Table 4

Gross Value Added by sectors in selected countries of Central and Eastern Europe ( \%)

\begin{tabular}{|c|c|c|c|c|c|c|c|c|c|c|c|c|}
\hline \multirow[b]{2}{*}{$\begin{array}{l}\text { Member } \\
\text { State }\end{array}$} & \multicolumn{3}{|c|}{ Agriculture } & \multicolumn{3}{|c|}{ Industry } & \multicolumn{3}{|c|}{ Construction } & \multicolumn{3}{|c|}{ Services } \\
\hline & $\begin{array}{l}\text { ষ } \\
\text { 유 }\end{array}$ & $\begin{array}{l}\text { 웅 } \\
\text { 유 }\end{array}$ & $\begin{array}{l}0 \\
\stackrel{1}{0} \\
\text { N }\end{array}$ & $\begin{array}{l}\text { ষ } \\
\text { 유 }\end{array}$ & $\begin{array}{l}0 \\
\stackrel{0}{1} \\
\text { N }\end{array}$ & $\begin{array}{l}0 \\
\stackrel{0}{0} \\
\stackrel{N}{N}\end{array}$ & $\begin{array}{l}\text { ষ } \\
\text { 유 }\end{array}$ & 웅 & $\begin{array}{l}0 \\
\stackrel{1}{0} \\
\text { N }\end{array}$ & $\begin{array}{l}\text { ষ } \\
\text { 유 }\end{array}$ & 웅 & 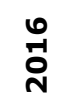 \\
\hline EU 28 & 2.0 & 1.6 & 1.5 & 20.2 & 19.2 & 19.4 & 6.0 & 5.8 & 5.3 & 71.8 & 73.4 & 73.7 \\
\hline Czech Rep. & 2.5 & 1.7 & 2.5 & 31.0 & 29.9 & 32.1 & 6.6 & 6.9 & 5.5 & 59.8 & 61.5 & 59.9 \\
\hline Estonia & 3.9 & 3.2 & 2.6 & 21.8 & 22.0 & 20.9 & 7.0 & 5.9 & 6.0 & 67.3 & 68.8 & 70.5 \\
\hline Latvia & 4.8 & 4.4 & 3.9 & 17.5 & 18.4 & 16.0 & 6.5 & 5.0 & 5.3 & 71.2 & 72.2 & 74.7 \\
\hline Lithuania & 4.6 & 3.3 & 3.3 & 25.4 & 23.2 & 22.2 & 7.2 & 5.8 & 6.5 & 62.7 & 67.6 & 68.0 \\
\hline Hungary & 5.0 & 3.5 & 4.4 & 25.7 & 25.7 & 26.8 & 5.3 & 4.2 & 3.7 & 64.0 & 66.6 & 65.1 \\
\hline Poland & 3.7 & 2.9 & 2.7 & 25.5 & 24.7 & 26.5 & 7.2 & 8.5 & 7.2 & 63.6 & 63.9 & 63.6 \\
\hline Slovakia & 4.1 & 2.8 & 3.7 & 30.1 & 26.3 & 26.9 & 6.1 & 8.9 & 7.9 & 59.7 & 62.0 & 61.5 \\
\hline
\end{tabular}

Source: author's calculation based on the data of European Statistical Office, 2017

According to these data, Polish agriculture lost almost half of its workplaces between 2000 and 2013. This is the most important and ongoing trend, related to global economic developments and 
previously observable in all advanced economies, especially in Mediterranean Region. The decrease in agricultural employment affects all Member States but in particular the countries with the highest participation of workplaces in farming. As mentioned above, not only employment but also the share of agriculture, fishing and forestry in total value added of the whole economy has decreased drastically in Poland, even though GVA in agriculture still remained relatively large in comparison with most other European Union economies in 2016, with the level of almost $3 \%$ (Table 4).

One of the crucial structural changes, observed in the primary sector, is the growing size of farms in Poland as an effect of land consolidation (Pasakarnis G. and Maliene V., 2010). During last decade, there has been a steady increase in the number of farms with large utilized agricultural area (UAA) (Table 5). However, there were still evident differences in the structure of agriculture across the EU. There were almost 11 million farms across the European Union in 2013 working with 174,6 million hectares of land ( $40.0 \%$ of the total land area of the EU). The average size of a farm in EU28 was about 16 hectares, and less than 8 hectares in Central and Eastern countries (approximately 6.4 million farms in the 13 new Member States).

Table 5

\section{Number of farms according to farm size (UAA) in selected countries of Central and Eastern Europe}

\begin{tabular}{|c|c|c|c|c|c|c|c|c|}
\hline \multirow{2}{*}{ Member State } & $<2$ & $2-4.9$ & $5-9.9$ & 10-19.9 & 20-29.9 & $30-49.9$ & $50-99.9$ & $>100$ \\
\hline & \multicolumn{8}{|c|}{2005} \\
\hline $\begin{array}{l}\text { Czech } \\
\text { Republic }\end{array}$ & 15240 & 7140 & 4720 & 4370 & 2130 & 2240 & 2150 & 4260 \\
\hline Estonia & 4870 & 7700 & 5570 & 4390 & 1650 & 1300 & 950 & 1320 \\
\hline Latvia & 29590 & 31270 & 30360 & 22260 & 6540 & 4220 & 2520 & 1900 \\
\hline Lithuania & 26520 & 103400 & 65870 & 36250 & 9020 & 5970 & 3430 & 2470 \\
\hline Hungary & 583850 & 57340 & 28960 & 18990 & 7570 & 6400 & 5650 & 6040 \\
\hline Poland & 1217880 & 532990 & 370200 & 237940 & 62860 & 33920 & 13470 & 7230 \\
\hline Slovakia & 56010 & 5650 & 1920 & 1200 & 520 & 590 & 630 & 1980 \\
\hline Member State & \multicolumn{8}{|c|}{2010} \\
\hline $\begin{array}{l}\text { Czech } \\
\text { Republic }\end{array}$ & 2270 & 1260 & 4180 & 3950 & 2060 & 2310 & 2420 & 4420 \\
\hline Estonia & 2360 & 4250 & 4070 & 3470 & 1480 & 1170 & 1090 & 1720 \\
\hline Latvia & 9910 & 18390 & 22660 & 17490 & 5670 & 3950 & 2740 & 2570 \\
\hline Lithuania & 32570 & 84830 & 39900 & 21470 & 6640 & 5870 & 4830 & 3800 \\
\hline Hungary & 455530 & 46060 & 26540 & 19430 & 7950 & 7440 & 6410 & 7450 \\
\hline Poland & 363180 & 468200 & 334950 & 218510 & 59970 & 35310 & 16840 & 9650 \\
\hline Slovakia & 9460 & 6290 & 2660 & 1630 & 730 & 700 & 780 & 2210 \\
\hline Member State & \multicolumn{8}{|c|}{2013} \\
\hline $\begin{array}{l}\text { Czech } \\
\text { Republic }\end{array}$ & 2990 & 1880 & 4940 & 4610 & 2360 & 2370 & 2460 & 4630 \\
\hline Estonia & 2200 & 4140 & 3970 & 3340 & 1400 & 1180 & 1150 & 1790 \\
\hline Latvia & 18710 & 16150 & 16090 & 15790 & 5320 & 4140 & 2700 & 2890 \\
\hline Lithuania & 24320 & 67100 & 38440 & 20070 & 6520 & 5560 & 5100 & 4680 \\
\hline Hungary & 373010 & 42550 & 25550 & 20160 & 8350 & 7490 & 6590 & 7640 \\
\hline Poland & 333590 & 444220 & 308200 & 208990 & 62040 & 40440 & 20570 & 10950 \\
\hline Slovakia & 7430 & 6450 & 2860 & 2220 & 770 & 730 & 790 & 2310 \\
\hline
\end{tabular}

Source: authors' calculation based on data from the European Statistical Office, 2017

On one hand, there was a large number ( 5.8 million) of very small farms (less than 2 hectares in size and only with less than $2.5 \%$ of the total land area that was used for farming) in all EU 
countries in 2010 (Martins C. and Tosstorff G., 2011). On the other hand, there was a small number ( $2.7 \%$ of all farms) of very large farms with over 100 hectares of UAA that farmed half of the farmland. In 2013 these differences were even greater, there were 4.9 million (45\%) of very small farms (less than 2 hectares in size and only with $2.0 \%$ of the total land area that was used for farming) and $3.1 \%$ of very large farms with over 100 hectares of UAA that farmed $52 \%$ of the farmland in all countries of the EU. These differences are similar in Poland, where not many farms over 100 ha $(0.76 \%$ of total number of farms) owned $21 \%$ of UAA (Table 6$)$. Nevertheless, the ownership of agricultural land is still highly fragmented (Hartvigsen M., 2014).

Table 6

Share of the area of agricultural land used by farms according to their regional groups in selected countries of Central and Eastern Europe $(\%)$

\begin{tabular}{|c|c|c|c|c|c|c|c|c|}
\hline \multirow{2}{*}{ Member State } & $<2$ & 2-4.9 & $5-9.9$ & 10-19.9 & 20-29.9 & $30-49.9$ & $50-99.9$ & $>100$ \\
\hline & \multicolumn{8}{|c|}{2005} \\
\hline Czech Republic & 0.3 & 0.6 & 0.9 & 1.7 & 1.4 & 2.4 & 4.2 & 88.3 \\
\hline Estonia & 0.8 & 3.0 & 4.8 & 7.4 & 4.8 & 6.0 & 7.8 & 65.4 \\
\hline Latvia & 1.5 & 6.2 & 12.7 & 18.1 & 9.3 & 9.4 & 10.2 & 32.7 \\
\hline Lithuania & 1.3 & 11.8 & 16.6 & 17.7 & 7.7 & 8.1 & 8.4 & 28.4 \\
\hline Hungary & 4.3 & 4.1 & 4.6 & 6.1 & 4.2 & 5.6 & 9.1 & 61.9 \\
\hline Poland & 5.9 & 11.7 & 17.9 & 22.1 & 10.3 & 8.6 & 6.1 & 17.4 \\
\hline Slovakia & 1.5 & 0.9 & 0.7 & 0.9 & 0.7 & 1.2 & 2.4 & 91.8 \\
\hline Member State & \multicolumn{8}{|c|}{2010} \\
\hline Czech Republic & 0.1 & 0.1 & 0.8 & 1.6 & 1.4 & 2.5 & 4.9 & 88.6 \\
\hline Estonia & 0.3 & 1.5 & 3.1 & 5.2 & 3.8 & 4.8 & 8.1 & 73.2 \\
\hline Latvia & 0.5 & 3.5 & 9.0 & 13.5 & 7.6 & 8.4 & 10.4 & 47.0 \\
\hline Lithuania & 1.7 & 9.7 & 10.1 & 10.8 & 5.9 & 8.3 & 12.0 & 41.6 \\
\hline Hungary & 2.9 & 3.0 & 3.9 & 5.7 & 4.1 & 6.0 & 9.5 & 64.7 \\
\hline Poland & 3.3 & 10.6 & 16.5 & 20.8 & 10.0 & 9.2 & 7.9 & 21.6 \\
\hline Slovakia & 0.5 & 1.0 & 1.0 & 1.2 & 0.9 & 1.4 & 2.9 & 91.1 \\
\hline Member State & \multicolumn{8}{|c|}{2013} \\
\hline Czech Republic & 0.1 & 0.2 & 1.0 & 1.8 & 1.6 & 2.6 & 4.9 & 87.8 \\
\hline Estonia & 0.3 & 1.4 & 3.0 & 5.0 & 3.6 & 4.8 & 8.4 & 73.5 \\
\hline Latvia & 0.8 & 2.9 & 6.2 & 11.7 & 6.9 & 8.5 & 10.0 & 53.1 \\
\hline Lithuania & 1.3 & 7.5 & 9.4 & 9.8 & 5.5 & 7.5 & 12.4 & 46.6 \\
\hline Hungary & 2.5 & 2.9 & 3.8 & 6.0 & 4.3 & 6.2 & 9.8 & 64.4 \\
\hline Poland & 3.0 & 10.0 & 15.1 & 20.0 & 10.4 & 10.6 & 9.7 & 21.1 \\
\hline Slovakia & 0.4 & 1.1 & 1.0 & 1.7 & 1.0 & 1.5 & 3.0 & 90.4 \\
\hline
\end{tabular}

Source: authors' calculation based on data from the European Statistical Office, 2017

When analysing the transformations in the agricultural sector in EU Member States, it is worth focusing also on the regional aspect. In scientific literature one can find the statement that one of the main factors inhibiting these transformations are the disproportions in the level of socioeconomic and environmental development in the countries of the Community, which are even more evident in the regional arrangement (Stec M., 2008; Dominiak J. and Churski P., 2012, Bluszcz A., 2016; Maciejewski M., 2017; Szopik-Depczynska K. et al., 2017). Similar conclusions can be drawn from the results of analysis of the level of agricultural development in Polish provinces. This is because the analysis conducted with the use of PERKAL's index (PI) allowed to indicate three groups of regions representing various types of agriculture in Poland. 
The main important feature that distinguishes Polish agriculture from other EU Member States are environmental conditions, which can include mainly soil quality, relief and water conditions. Important for the development of agricultural production in Poland is also spatial diversification of the agrarian structure. Agrarian structure consists of the share (shaped by history and changing over time) of different forms of ownership in land use. It also involves classification according to the share of farms in individual area groups (area size classes), classification of farms according to their economic size, labour force or capital resources. When conducting only the analysis of the agrarian structure (understood as the share of farms of given area size classes) and relating its results to various farm area groups, one can observe considerable structural diversification in agriculture in Poland (Musial W., 2015).

The conducted analysis shows that the group with the highest level of agricultural development (A) included Wielkopolskie, Zachodnio-Pomorskie and Warminsko-Mazurskie provinces that have clearly the best agrarian structure and better agricultural condition compared to the others (Figure 1). These regions also have the greatest share in commercial production generated in Polish agriculture, which results from the fact that they belong to valuable (in terms of quality) resources of the natural environment. At the same time, these provinces are dominated by large farms built on the foundations of the socialist form of land ownership (functioning between 1949 and 1993), i.e. State Agricultural Farms (Polish: Panstwowe Gospodarstwa Rolne - PGR), and their favourable location in relation to domestic and foreign markets allows to reach high profitability from agricultural activities (Ossowska L. and Janiszewska D. A., 2013).

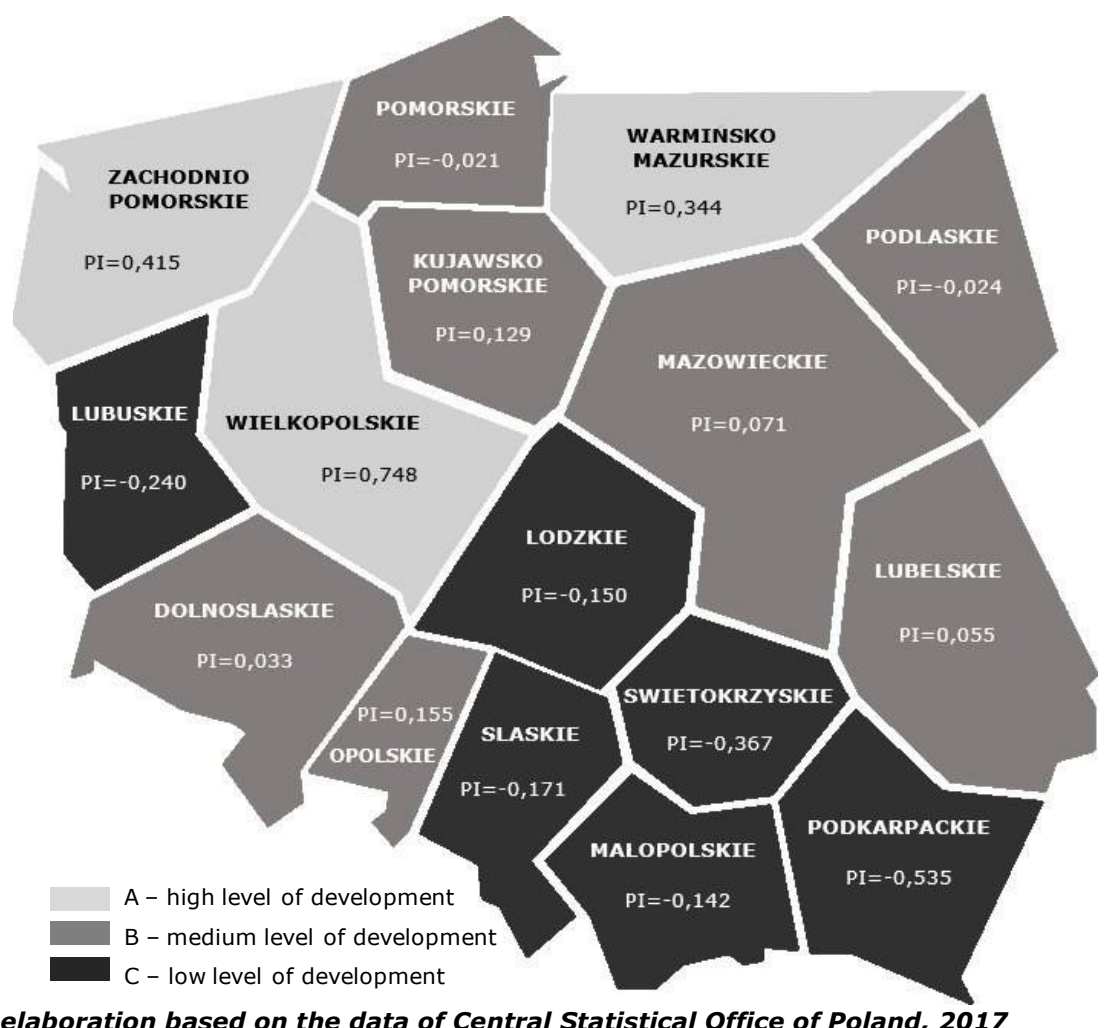

Source: author's elaboration based on the data of Central Statistical Office of Poland, 2017

Fig. 1. Spatial diversification of the level of agricultural development in the regions of Poland

Regions in south-eastern Poland which (along with Lubuskie Province) were classified into the group with the lowest level of development (C) have different conditions for agricultural development. On the background of the country, these provinces are distinguished by exceptionally high agrarian fragmentation and a small average area of farms operating on them. Agricultural 
development in these regions is also limited by the occurrence of less-favoured areas (LFA), which include: lowland zones with low productivity; mountain and foothill zones with technological, climatic and topographical difficulties in conducting agricultural production; and areas with specific difficulties generated by, for instance, industry. Therefore, the economic situation of farms located in this region can be regarded as relative technological backwardness with poor and underperforming business entities (Musial W. and Wojewodzic T., 2015).

The most numerous group of provinces are those with an average level of agricultural development, classified into group B. These regions are also varied within the group they form, which is evidenced by the variability of the determined values of PERKAL's indices (PI). This group includes provinces with favourable conditions for management in the agricultural sector, i.e. with a high share of large-area farms, favourable labour force and a high level of technical equipment of farms which have been showing great dynamism of changes since Poland's accession to the EU. It also includes provinces where the importance of the agricultural sector in shaping the profile of the economy (functioning in areas with difficult environmental-climatic and soil conditions, surrounded by protected areas, i.e. national parks, landscape parks and Natura 2000 areas) at a regional level has been diminishing in recent years. This necessitates responsible and rational management of land resources in a manner reconciling the interests of nature and those of agriculture.

\section{Conclusions}

Integration of Central and East European countries with EU structures after 2004 caused clear controversy and raised concerns both in the newly admitted countries and in the so-called "old" Union countries. This is because the newly admitted units belonged to the group of socioeconomically less developed countries, the majority of which are the Eastern Bloc countries, characterized by a large share of the agricultural sector in domestic production and employment. Therefore, they posed a serious competitive challenge for the countries forming the then market of the Community. However, over time, these concerns turned out to be groundless, and the impulse generated by accession and the need to satisfy the requirements of the Common Agricultural Policy, and also to compete on the Community market brought benefits both for the existing and new EU countries, forcing (among other things) a range of positive changes in the structure of production and employment in individual sectors of their economy.

This is because results of the conducted research show that the increase in economic level in most of the analyzed central and East European Countries was accompanied by a gradual decline in the share of production and employment in agriculture in favour of industry, and above all the sector of services in the generated gross value added. However, it should be mentioned that these changes did not occur at the same rate and did not reach a similar range, which applies particularly to regions of the studied countries. The conducted assessment of the level of agricultural development using PERKAL's method of standardized sums showed that despite deep developmental transformations taking place in the Polish agricultural sector between 2004 and 2016, regional disproportions in this respect can still be noticed. This is because the abovementioned issues are a result of intensification of the process of specialization and modernization in agriculture, the best example of which is the increase of the average area of a farm as well as the increase in efficiency and profitability of agricultural production in some regions of Poland.

However, the conducted research focuses on the current state, which is the consequence of dynamic socio-economic transformations taking place in rural areas thanks to the intense inflow of 
financial capital from the Community's budget, as a result of both the pre-accession period and the period of Poland's membership. However, such a condition can change after 2020, when the countries that entered the EU after 2004 might strongly feel the effects of a decreased (in terms of the scale) extent and magnitude of financial support. This is because this situation can make the first sector of economy once again become a place where the unemployed will seek their chance and agriculture may once again be regarded as a buffer allowing to absorb potential shocks in the labour market, which can take place in the economies of the Community's countries, particularly taking into account the challenges the Community has to face, to which even now one can include future economic crises, global migration problems or the so-called 'BREXIT'.

\section{Acknowledgements}

The publication was funded by the Ministry of Science and Higher Education of the Republic of Poland.

\section{Bibliography}

1. Bluszcz, A. (2016). Classification of the European Union Member States According to the Relative Level of Sustainable Development. Quality \& Quantity, No. 50(60), pp. 2591-2605.

2. Dominiak, J., Churski, P. (2012). The Role of Innovation in the Formation of Regions of Development and Those of Economic Stagnation in Poland. Regional and Local Studies, No. 4(46), pp. 54-77.

3. Grabinski, T. (1984). Multivariate Comparative Analysis in Research Over Dynamics of Economic Phenomena. Wydawnictwo Akademii Ekonomicznej, Krakow.

4. Hartvigsen, M. (2014). Land Reform and Land Fragmentation in Central and Eastern Europe. Land Use Policy, No. 36, p. 331-340.

5. Kukula, K. (2000). Metoda unitaryzacji zerowanej (The Zero-unitarization Method). Wydawnictwo Naukowe PWN, Warszawa.

6. Maciejewski, M. (2017). The Problems of the Economic Development of the European Union Member States. Studia Ekonomiczne. Zeszyty Naukowe Uniwersytetu Ekonomicznego w Katowicach, No. 319, pp. 117-126.

7. Martins, C., Tosstorff G. (2011). Large Farms in Europe. Statistics in Focus, No. 18, pp. 1-7.

8. Mlodak, A. (2006). Analiza taksonomiczna w statystyce regionalnej (Taxonomic Analysis in Regional Statistics). Wydawnictwo Difin, Warszawa.

9. Mountain areas in Europe: Analysis of Mountain Areas in EU Member States. Acceding and Other European Countries. Final Report. (2004).

Retrieved: http://ec.europa.eu/regional_policy/sources/docgener/studies/pdf/montagne/mount1.pdf. Access: 25.01.2018.

10. Musial, W. (2015). Regionalne zroznicowanie rolnictwa rodzinnego w Polsce - wybrane aspekty (Regional Diversification of Agriculture Family in Poland - Selected Aspects. In. A. Chlebicka (Ed.) Ekonomiczne mechanizmy wspierania i ochrony rolnictwa rodzinnego w Polsce i innych panstwach Unii Europejskiej (Economic Mechanisms to Support and Protect Family Farming in Poland and Other European Union Countries). Ministerstwo Rolnictwa i Rozwoju Wsi, Fundacja Programow Pomocowych dla Rolnictwa FAPA, Warszawa, p. 89-108.

11. Musial, W., Wojewodzic, T. (2015). Zroznicowanie regionalne rolnictwa rodzinnego i sytuacja produkcyjnoekonomiczna rodzinnych gospodarstw rolnych funkcjonujacych w roznej strukturze agrarnej (Regional Diversification of Family Farming and the Production and Economic Situation of Family Farms Functioning in Various Agrarian Structures). In M. Podstawka (Ed.), Ekonomiczne i prawne mechanizmy wspierania $i$ ochrony rolnictwa rodzinnego (Economic and Legal Mechanisms to Support and Protect Family Farming). Ministerstwo Rolnictwa i Rozwoju Wsi, Fundacja Programow Pomocowych dla Rolnictwa FAPA, Warszawa, p. 26-45.

12. Ossowska, L., Janiszewska, D. A. (2013). The Production Potential and Agricultural Development Determinants in Zchodniopomorskie Voivodeship. Zeszyty Naukowe Szkoły Głownej Gospodarstwa Wiejskiego. Problemy Rolnictwa Światowego, No. 13(2), 68-78. pp. 68-78.

13. Paluch, Ł. (2015). Zastosowanie taksonomii w procesie pomiaru i oceny poziomu rozwoju społecznogospodarczego jako efektu realizowanej polityki spolecznej (Application of Taxonomy in the Process of Measuring and Assessing the Level of Socio-economic Development as an Effect of the Implemented Social Policy). In M. Kowalska (Ed.), Wybrane aspekty polityki społecznej w Polsce - podręcznik dla studentów kierunków społecznych, ekonomicznych i rolniczych (Selected Aspects of Social Policy in Poland - a Handbook for Students of Social, Economic and Agricultural Studies). Wydawnictwo Uniwersytetu Rolniczego, Krakow, p. 199-225.

14. Parris, T. M., Kates, R. W. (2003). Characterizing and Measuring Sustainable Development. Annual Review of Environment and Resources, No. 28, pp. 559-586. 
Proceedings of the 2018 International Conference "ECONOMIC SCIENCE FOR RURAL DEVELOPMENT" No 47

Jelgava, LLU ESAF, 911 May 2018, pp. 238-248

DOI 10.22616/ESRD.2018.028

15. Pasakarnis, G., Maliene V. (2010). Towards Sustainable Rural Development in Central and Eastern Europe: Applying Land Consolidation, Land Use Policy, No. 27, p. 546-548.

16. Perkal, J. (1953). O wskaznikach antropologicznych (About Anthropological Indicators). Przeglad antropologiczny, No. 19, pp. 209-219.

17. Pogorzelski, K. (2014). Agricultural Development and Structural Change, IBS Policy Paper 05/2014. Retrieved: http://ibs.org.pl/app/uploads/2015/10/IBS_Policy_Paper_05_2014_eng.pdf. Access: 27.01.2018.

18. Potori, N., Chmielinski, P., Andrew, F. F. (2014). Structural Changes in Polish and Hungarian Agriculture Since EU Accession: Lessons Learned and Implications for the Design of Future Agricultural Policies. Research Institute of Agricultural Economics, Budapest, pp. 9-23.

19. Stec, M. (2008). Comparison of European Union Countries by Development Level. National Economy, No. 19(7-8), pp. 99-118. 